\title{
A Review of Ice Core Drilling in Cave Environment - Challenges, Achievements and Future Directions
}

\author{
Zoltan Kern ${ }^{1 *}$ and Aurel Perșoiu ${ }^{2,3,4 *}$ \\ ${ }^{1}$ Institute for Geological and Geochemical Research, Research Centre for Astronomy and Earth Sciences, Eötvös Loránd \\ Research Network, Budapest, Hungary, ${ }^{2} E$ mil Racoviță Institute of Speleology, Romanian Academy, Cluj-Napoca, Romania, \\ ${ }^{3}$ Stable Isotope Laboratory, Ştefan cel Mare University, Suceava, Romania, ${ }^{4}$ Romanian Institute of Science and Technology, Cluj- \\ Napoca, Romania
}

\section{OPEN ACCESS}

Edited by:

Davide Tiranti,

Agenzia Regionale per la Protezione Ambientale (ARPA), Italy

Reviewed by:

Luca Paro,

Agenzia Regionale per la Protezione Ambientale (ARPA), Italy

Giandomenico Fubelli,

University of Turin, Italy

*Correspondence: Zoltan Kern zoltan.kern@gmail.com Aurel Perșoiu

aurel.persoiu@gmail.com

Specialty section:

This article was submitted to Quaternary Science, Geomorphology and Paleoenvironment,

a section of the journal Frontiers in Earth Science

Received: 03 June 2021 Accepted: 28 December 2021

Published: 24 January 2022

Citation: Kern Z and Perșoiu A (2022) A Review of Ice Core Drilling in Cave Environment

- Challenges, Achievements and Future Directions.

Front. Earth Sci. 9:720038 doi: 10.3389/feart.2021.720038
Worldwide, more than $141 \mathrm{~m}$ of ice cores has been extracted from 20 cave ice deposits, with the drilling projects focusing mainly in Central European caves. The fact that half of the cave ice cores (3 out of 6) published in 2020 represent non-European localities, however, predicts that an increasing number of cave ice drilling projects will be carried out in the near future in other geographical areas hosting ice caves. Based on the gathered experience the most commonly encountered technical challenge of ice-core drilling problems in cave environment is englacial rocky/woody debris. The complex stratigraphy of cave ice deposits represents a crucial methodological problem. We propose an (Cave Ice Sedimentary Architecture and Deposition - CISAD) approach to take into consideration of the stratigraphic peculiarities of the investigated cave ice deposit and additional crucial meta-data before establishing the location of a drilling site best-suited to obtain the highest quality paleoenvironmental data.

Keywords: ice cave, ice core, drilling, paleoclimate, stratigraphy

\section{INTRODUCTION}

Ice cores recovered from glaciers have provided several of the longest, oldest and highest-resolution records of climate variability during the mid-to-late Quaternary (Jouzel, 2013). While polar and alpine glaciers have been generally targeted by such studies, the quest to understand past climate variability led to the expansion of drilling efforts towards "non-traditional" perennial ice accumulation such as ice wedges (Meyer et al., 2015; Opel et al., 2018), rock glaciers (Cecil et al., 1998; Krainer et al., 2015) and cave ice. While the first ice core from a cave ice deposit was extracted from Scărişoara Ice Cave (Romania) in 1947 (Serban et al., 1948) and thus the history of cave ice drilling activity is comparable to the semicentennial history of ice core drillings in polar (Dansgaard, 2004; Langway, 2008) and alpine (Oeschger et al., 1977) regions, the field gained more traction only in the past decade. Thus, several studies in Europe in the early 2000s (Citterio et al., 2004; Fórizs et al., 2004; Kern et al., 2004; Holmlund et al., 2005) have proved the potential of perennial ice caves to host valuable, high-resolution, long records of past environmental variability. Building on the early studies, in the 2010s, new ice cores were drilled in caves in Europe, North America and Asia (see below).

While ice core drilling campaigns in the more traditional polar and alpine environment face numerous challenges (Jouzel, 2013; Talalay, 2014; Talalay et al., 2015), cave ice drilling efforts received much less attention and their achievements and challenges have been generally restricted to the small ice caves community (Perşoiu and Lauritzen, 2018). Given the peculiar nature of ice 
formation and dynamics in caves and the associated glacial, periglacial and karst-specific processes, drilling in cave glaciers and extracting continuous ice cores have proved a challenge for all teams involved. Various methods, techniques and equipment have been used with diverse degrees of success.

In this paper, we summarize the achievements and the main challenges of cave ice drilling efforts of the past 70 years and identify the best solution available considering both the peculiarities of cave ice deposits and the potential research questions that could be addressed. The article is structured as follows: in section 2, we present the main mechanisms of cave ice formation and the resulting ice bodies; section 3 is dedicated to a brief overview of the past cave ice drilling efforts and the methods used during the past 30 years and in section 4 we discuss potential approaches to maximize the results.

\section{PERENNIAL ICE ACCUMULATION IN CAVES}

Perennial ice accumulations in caves are found in most karst regions of the Northern Hemisphere, in a latitudinal band stretching between $\sim 19$ and $80{ }^{\circ} \mathrm{N}$ (Pflitsch et al., 2016; Barton et al., 2020), and from $30 \mathrm{~m}$ a.s.l. (above sea level) in Svalbard (Lauritzen et al., 2018) to 3,350 m a.s.l. (above sea level) on Mount Alberta, Canada (Yonge et al., 2018). The most significant processes responsible for the formation of perennial ice deposits in caves are freezing of water and snow accumulation, with glacial intrusion and hoarfrost deposition playing only minor roles (Perşoiu and Lauritzen, 2018; Kwiecien et al., 2022). Snow deposits occur at the base of near vertical entrance shafts in high-to-mid altitude mountains, forming deposits up to $80 \mathrm{~m}$ in thickness (Perşoiu and Onac, 2019). The reduced thickness of the snowpack does not result in pressures high enough to compact snow to ice (Langway et al., 1993). In most of the cases, the deposits consist of firn (density well below $0.83 \mathrm{~g} / \mathrm{cm}^{3}$ ) with intercalated layers of ice, formed by freezing of meltwater percolated through the snow mass. Contrary, ice formed by the freezing of water, so-called congelation ice, attains a density approaching the upper limit for ice $\left(0.917 \mathrm{~g} / \mathrm{cm}^{3}\right)$. The freezing process (Perşoiu et al., 2011) occurs as both thin films of inflowing water form successive layers of ice (floor ice) or as stagnant water freezes from top to bottom, to form a thick layer of ice trapping allochthonous sediments, insitu forming cryogenic cave calcite (CCC, Žák et al., 2008) and occasional air bubbles (lake ice).

The vast majority of existing cave glaciers in caves are formed by water-freezing processes. They have formed since at least the early Holocene (Perşoiu et al., 2017; Sancho et al., 2018), experiencing periods of growth and decay, under the complex interplay of seasonally varying air temperatures and precipitation amounts (Stoffel et al., 2009; Spötl et al., 2014; Kern et al., 2018). The various climate and environmental proxies archived in these deposits (e.g., isotopologues of water and CCC, pollen, surfacederived sediments) offer a unique window in the past history of the environment and have been targeted with increased scrutiny over the past decades.

\section{PAST CAVE ICE DRILLING PROJECTS}

The first documented cave ice core was extracted from Scărișoara Ice Cave (Romania) in 1947 (Serban et al., 1948), and additional trials were performed in the 1960s (Serban et al., 1967) although these first attempts could extract only short $(<1 \mathrm{~m})$ ice cores. Following these pioneer works there was a halt in the cave ice drilling projects for more than 3 decades. The next documented ice core (and the first outside Europe) was extracted from Candelaria Ice Cave (New Mexico, United States) in 1995 (Dickfoss et al., 1997). Subsequently, Europe became the hot spot of cave ice drilling activities during the first decades of the 21 st century. Twenty-three drilling projects took place in 20 ice caves (Table 1) and the total length of the extracted ice cores is $\sim 141 \mathrm{~m}$ (Figure 1A). First reports of cave ice drilling projects have usually been published following the biennial International Workshops on Ice Caves (IWIC). All but one cave ice drilling campaigns documented in the scientific literature were performed in the temperate mid-latitudes of the northern Hemisphere (Figure 1B). The only cave ice core representing a polar latitude was extracted from Svarthammarhola (Norway) (Lauritzen et al., 2005). The publication evidence shows the greatest concentration of cave ice cores in Central Europe, the Southern Alps (Italy and Slovenia) and the Western Carpathians (Romania) (Figure 1A). Replicated ice cores were extracted from subterranean ice deposits only in Romania and Cave 29 (New Mexico, United States) (Table 1).

The main objectives of these drilling projects were to reconstruct past climate variability using the isotopologues of water as climate proxies, a process initiated through the pioneering work of Serban et al. (1967) shortly after similar efforts were initiated in Greenland. These early efforts were continued in 20th century, with varying degrees of success, mostly due to difficulties in building reliable chronologies of ice accumulation (Kern, 2018). Thus, cave ice-based studies addressed the geochemistry and stable isotope geochemistry of cave ice (Kern et al., 2009; Kern et al., 2011a; Kern et al., 2011b; May et al., 2011), the dynamics of past winter (Perşoiu et al., 2017) and summer (Bădăluță et al., 2020) air temperatures, past environmental and vegetation changes (Feurdean et al., 2011; Sancho et al., 2018; Leunda et al., 2019) and the dynamics of cave ice accumulations (Stoffel et al., 2009; Perșoiu and Pazdur, 2011; Spötl et al., 2014; Kern et al., 2018). Over the past few years, several studies investigated microorganism in cave ice deposits, with specifically designed drilling strategies (Sattler et al., 2013; Itcus et al., 2018) allowing the recovery of millennia-old microbial (Mondini et al., 2019; Paun et al., 2019) and fungal (Brad et al., 2018) communities. Considering the wide geographical distribution of potential and confirmed area of cave glaciation (Mavlyudov, 2008; Mavlyudov, 2018) the current overrepresentation of Europe does not reflect the spatial distribution of the known ice caves in the World. There is great potential in cave ice science, including drilling the cave ice deposits, outside Europe as well. Interestingly, three of the six published cave ice drilling projects were carried out in non-European ice caves (Cave 29, New Mexico, United States - Onac et al., 2020, Kinderlinskaya and Askinskaya caves, Russia - Trofimova et al., 2020) in the closing year of the data collection of this review 
TABLE 1 | Published cave ice drilling activities during the past 25 years.

\begin{tabular}{|c|c|c|c|c|c|}
\hline Cave & Country & $\begin{array}{c}\text { Max ice } \\
\text { thickness (m) }\end{array}$ & Drilling technique & $\begin{array}{l}\text { Max core } \\
\text { length (m) }\end{array}$ & Reference \\
\hline Eisriesenwelt & Austria & $\sim 7$ & electromechanical (not detailed) & 7.1 & May et al. (2011) \\
\hline Dachstein-Mammuthöhle & & $\sim 7$ & Manual & 6.5 & Kern et al. (2011a) \\
\hline Hundsalm Eis- und Tropfsteinhöhle & & $>7$ & Manual & 1.5 & Sattler et al. (2013) \\
\hline Vukusic Ice Cave & Croatia & $>10$ & Manual & 2.5 & Kern et al. (2011b) \\
\hline Schellenberger Eishöhle & Germany & - & not reported & 8 & Maggi et al. (2020) \\
\hline LoLc1650 & Italy & $\sim 15$ & SIPRE & 1.20 & Citterio et al. (2004) \\
\hline Vasto Ice Cave & & 8.3 & SIPRE & 7.8 & Colucci et al. (2016b) \\
\hline Leupa Ice Cave & & - & SIPRE & $\sim 1$ & Colucci et al. (2017) \\
\hline Ledena Pecina & Montenegro & n.d. & Manual & 1.99 & Kern et al. (2007a) \\
\hline Svarthammarhola & Norway & $\sim 20$ & $\mathrm{PICO}$ & 5 & Lauritzen et al. (2005) \\
\hline \multirow[t]{3}{*}{ Focul Viu Ice Cave } & Romania & $\sim 20^{\mathrm{a}}$ & Manual & 6.67 & Kern et al. (2004) \\
\hline & & & SIPRE & 8.26 & Maggi et al. (2008) \\
\hline & & & modified PICO & 4.87 & Bădăluță et al. (2020) \\
\hline \multirow[t]{2}{*}{ Scărișoara Ice Cave } & & $>22$ & PICO & 22.53 & Holmlund et al. (2005) \\
\hline & & & modified PICO & 25.3 & Bădăluță et al. (2018) \\
\hline Bortig Ice Cave & & $\sim 21$ & Manual & 2.05 & Kern et al. (2007b) \\
\hline Askinskaya Cave & Russia & - & manual (PI-8) & 2 & Trofimova et al. (2020) \\
\hline Kinderlinskaya Cave & & - & & 2 & \\
\hline Dobsinska Ice Cave & Slovakia & 26.5 & electromechanical (not detailed) & 13.93 & Vrana et al. (2007) \\
\hline Snežna Cave & Slovenia & - & SIPRE & 2 & Carey et al. (2020) \\
\hline Monlési lce Cave & Switzerland & $12-15$ & FELICS & $1.7^{\mathrm{b}}$ & Luetscher et al. (2007) \\
\hline Candelaria Ice Cave & United States & $\sim 4.5$ & not reported & 1.88 & Dickfoss et al. (1997) \\
\hline \multirow[t]{2}{*}{ Cave 29} & & $<3$ & Kovacs-II corer & 2 & Onac et al. (2018) \\
\hline & & & manual (Bosch) & 0.59 & Onac et al. (2020) \\
\hline
\end{tabular}

${ }^{a}$ Given in Maggi et al., 2008.

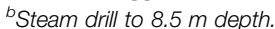

(Table 1). This may suggest that cave ice drilling projects may also start in parts of the geographical distribution range of ice caves outside Europe in the near future.

With few exceptions, where the morphology of the caves and ice blocks allowed for direct access to lower (and thus older) ice layers, most of the drilling efforts were concentrated on drilling vertical boreholes through the ice. Thirteen of the 23 ice core drilling projects employed a machine operated auger and simple manual drilling device was used in eight projects (no technical details were reported for 2 cases, Table 1). Because several of the largest ice caves (e.g., Scărișoara Ice Cave in Romania, DachsteinRieseneishöhle in Austria) are managed as show caves, the installed electric wiring allowed operating a drilling device driven by an electric motor in these caves. Light-weight, portable drill systems developed by and named after the Snow, Ice and Permafrost Research Establishment (SIPRE, Rand and Mellor, 1985) and Polar Ice Coring Office (PICO, Koci and Kuivinen, 1984) were used most frequently in these cases (Table 1).

Complete darkness in the caves and the general remote location of ice deposits within caves challenges the use of solar powered drilling devices, so a solar-powered drilling rig (FELICS abbreviated from Fast Electromechanical Lightweight Ice Coring System, Ginot et al., 2002) was used only for one project (Monlési Ice Cave, Luetscher et al., 2007). Poor ventilation in caves further excluded the usage of on-spot generated electric energy (health risk and cave pollution impact due to stagnation of exhaust fume). In a special situation a generator was operated outside the Focul Viu Ice
Cave (Maggi et al., 2008; Bădăluță et al., 2020). Thus, due to limitations in access to the caves, manual augers were usually the only available drilling option. The most frequently applied device consisted of a self-designed simple walled auger coupled to an Eijkelkamp soil auger handle and rod system. The main weaknesses of this system are that the undisturbed sampling is not assured and the relatively small diameter of these augers strongly limited the available ice amount to be recovered (Kern et al., 2007b).

\section{CHALLENGES AND SUGGESTIONS FOR FUTURE ICE CORE DRILLING PROJECTS IN CAVES}

The "best" cores recovered from cave glaciers should contain an undisturbed sequence of ice layers, with no hiatuses induced during drilling and capable to offer data that responds to multiple research questions. All these are challenged by the characteristics of the ice itself and of the ice blocks, the processes acting after deposition and the difficulties of drilling in a cold, dark and remote environment. In the following, we will discuss the main issues and propose potential solutions (or at least suggestions to be improved upon).

The main challenges encountered during drilling cave ice deposits result from the nature of the ice itself (see section 2 above). Combining the high density of the ice with the (generally) low power (electric or manual) applied to the drilling machines results in low penetration speeds. The succession of clear ice and 


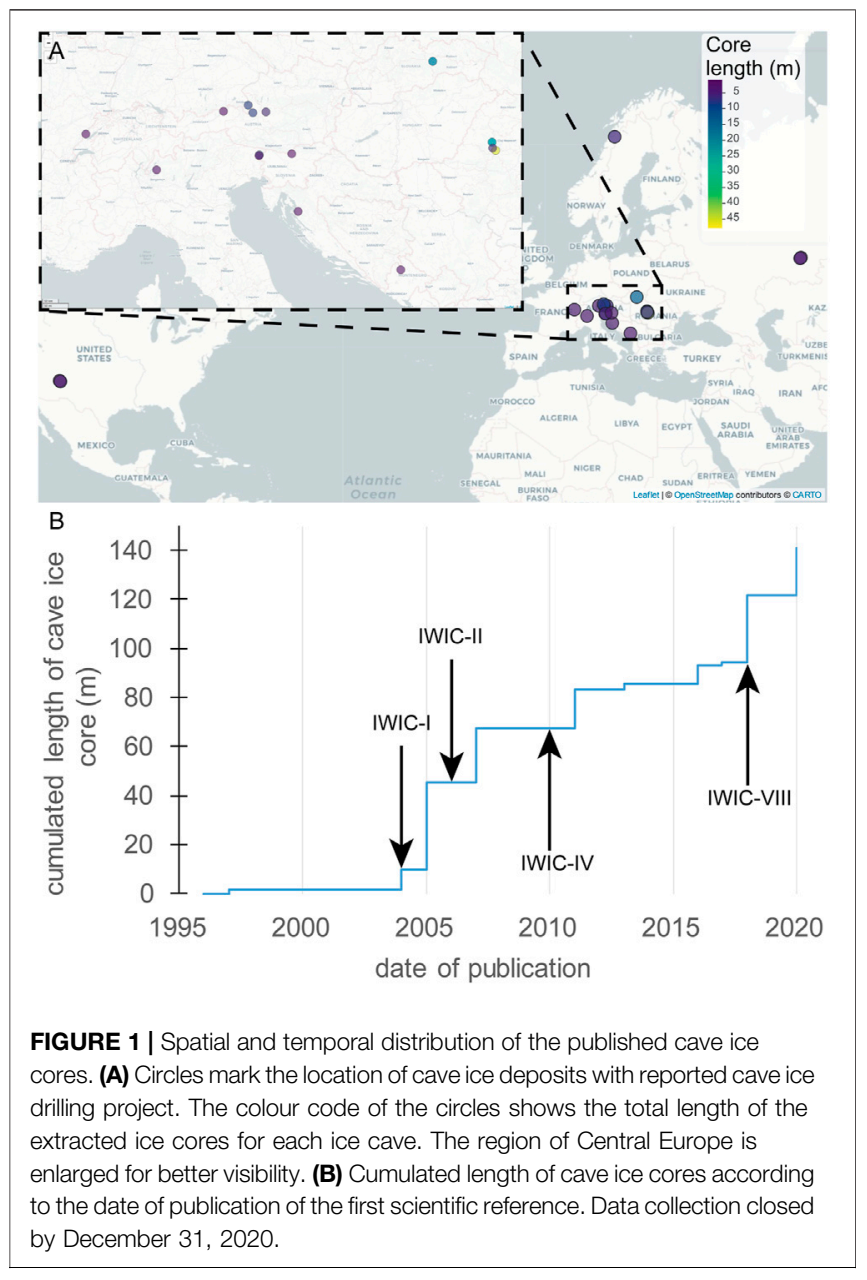

layers of impurities (containing both cryogenic cave calcite and surface-derived sediments) that build-up most of the cave ice blocks results in a sedimentary structure with very low cohesivity between the individual layers, prone to shearing, thus resulting in low-quality ice cores. Second, once formed, cave ice blocks have a dynamic that is shaped by both glacial and karstic-specific processes (Perşoiu and Lauritzen, 2018). The high plasticity of ice, combined with the usually inclined topography of the cave floor and the possible presence of breakdowns below the ice, leads to slow flow-like movement of the entire ice mass. The flow is further complicated by the uneven melting at the sole and sides of the ice blocks and the morphology of the surrounding walls, so that folds and tilting of the ice layers up to the vertical (Figure 2) are a common occurrence (Perşoiu and Pazdur, 2011; Spötl et al., 2014). Additionally, as most of the ice caves are located close to or well below the altitude of the $0^{\circ} \mathrm{C}$ isotherm, annual melting affects both the surface and sides of the ice blocks, with extreme ablation events possibly leading to the ablation of several years' worth of annual accumulation (Colucci et al., 2016a; Perşoiu et al., 2021). Ablation could affect either the entire surface of an ice block or only part of it, and also acts on time scales ranging from years to centuries.

Ice cave monitoring studies reported cave ice temperature usually in the range of -4 to $0^{\circ} \mathrm{C}$ (Luetscher et al., 2008; Strug et al., 2008). Attempting of core drilling in such warm ice is not recommended with the SIPRE augers (U.S. Ice Drilling Program, 2019). Drilling ice close to melting point, is extremely difficult with electromechanical drills because as the drill penetrates into warm ice, the ice particles from the cutting area melt and freeze again in a stiff mass stuck on the cutting ring face (Murariu et al., 2013) and the performance of the drill rapidly deteriorates to a point where penetration
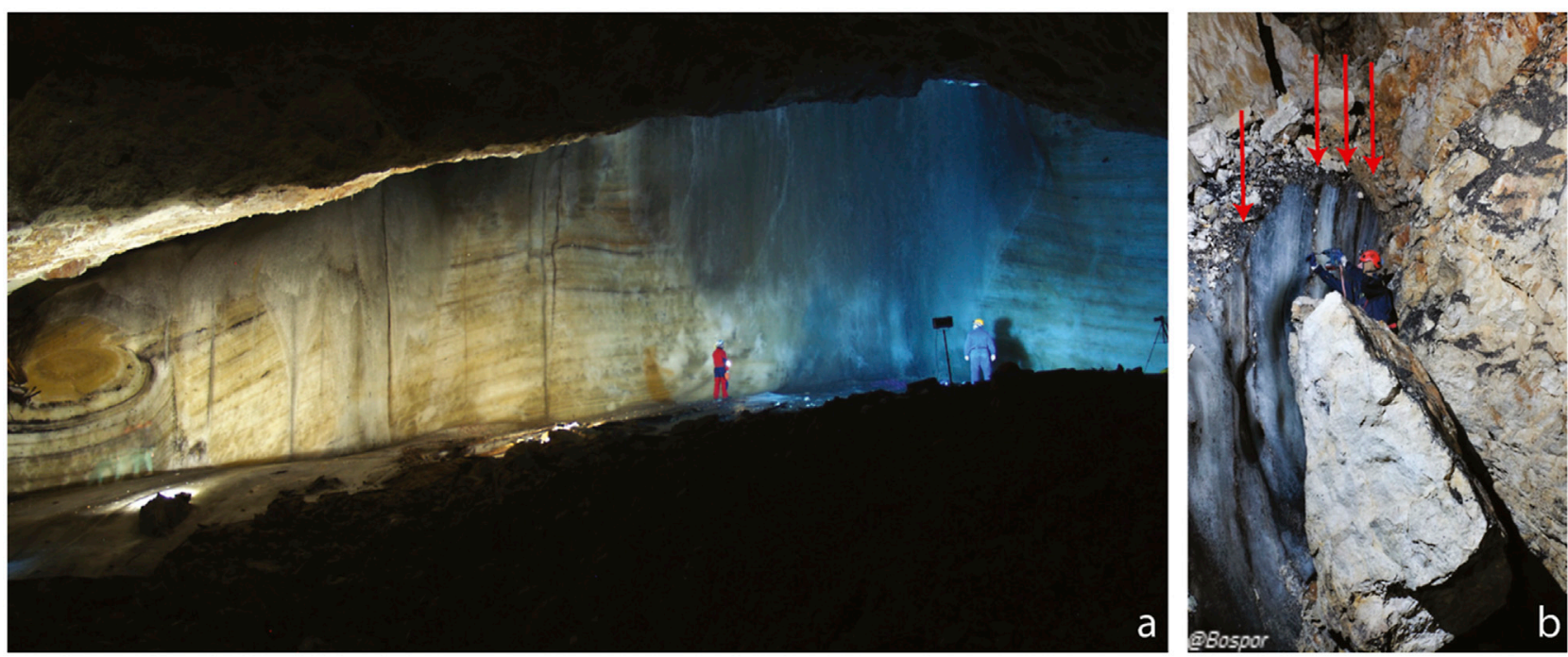

FIGURE 2 | Example of post-depositional modifications of ice layering. (A) The ice wall in the Little Reserve, Scărișoara Ice Cave, Romania. Individual layers have different degrees of inclination, making cores drilled in different section of the ice block intersecting layers of different age at the same depth. Newly formed ice covers part of the old ice in the center- left (blue ice between the two cavers). (B) Ice layers tilted to near vertical (indicated by the red arrows) in Crna Ledenica Cave, Croatia (photo by Željko Marunčić Bospor). 
TABLE 2 | The main problems and solutions in ice core drilling in cave environment.

\begin{tabular}{|c|c|c|c|}
\hline \multicolumn{2}{|c|}{ Problem } & \multirow[t]{2}{*}{ Cause } & \multirow{2}{*}{$\begin{array}{l}\text { Solution } \\
\text { avoiding such objects visible under the ice surface, GPR } \\
\text { survey to check major objects in deeper ice layers }\end{array}$} \\
\hline 1 & $\begin{array}{l}\text { Drilling stopped and drill hole was } \\
\text { abandoned }\end{array}$ & & \\
\hline 2 & Broken core & CCC layers creating shearing surfaces & High speed drilling \\
\hline 3 & - & Vibrating extension rods & $\begin{array}{l}\text { Modify the connections between the extension rods to make } \\
\text { the entire pole rigid }\end{array}$ \\
\hline 4 & $\begin{array}{l}\text { Skidding of cutters on top of the ice at the } \\
\text { bottom of the hole }\end{array}$ & Refrozen water and CCC & $\begin{array}{l}\text { Screws inserted between the cutters to scratch the top of the } \\
\text { hardened surface }\end{array}$ \\
\hline 5 & Blocked drill in the drilling hole & $\begin{array}{l}\text { Heat generated by friction melting of the ice and keeping a } \\
\text { motionless auger at the bottom of the drill hole resulted in } \\
\text { quick freezing of water }\end{array}$ & $\begin{array}{l}\text { Removal of the auger immediately }(<1 \mathrm{~s}) \text { after engine stop } \\
\text { (Several) reversals of the rotation direction } \\
\text { Alcohol usage to lower the freezing temperature (and } \\
\text { subsequent abandonment of the drill hole) }\end{array}$ \\
\hline 6 & $\begin{array}{l}\text { Ice chips at the bottom of the drill hole, } \\
\text { machine idling on top a rotating ice mass }\end{array}$ & $\begin{array}{l}\text { Warm }\left(0 \text { to }-2^{\circ} \mathrm{C}\right) \text { temperatures and broken ice chips } \\
\text { accumulating at the bottom of the drill hole }\end{array}$ & $\begin{array}{l}\text { Removal of the ice chip mass (bent spoon attached to the } \\
\text { extension rod), varying the speed without stopping the } \\
\text { engine, abandonment of the drill hole }\end{array}$ \\
\hline
\end{tabular}

stops (Talalay et al., 2015). As a practical solution it was suggested that the drillers can be forced to stop, bring back up the core barrel frequently and the drilling can be continued after cleanout the ice (Murariu et al., 2013), an approach that was successfully used in Scărișoara Ice Cave (Romania).

Clastic and organic debris are commonly observed in cave ice deposits and represent another type of difficulty seldom experienced in surface ice bodies. Clastic debris is produced by periglacial processes leading to intense weathering of the cave walls and continuous accumulation (and subsequent incorporation in ice) of pieces of limestone of varying sizes. Cave ice drilling projects frequently reported that such rocky (Luetscher et al., 2007; Vrana et al., 2007; Sattler et al., 2013; Bădăluță et al., 2020) or woody (Kern et al., 2004; 2011b) debris embedded in the ice caused problems or completely stopped the drilling effort. The coarse rocky debris can wear out the cutting edge of the auger in a relative short time, so an easily replaceable cutting teeth system can be required in the field (see section 4.1). Obviously the spots with large rocks or logs visible in a shallow depth in the transparent ice must be avoided when looking for a drilling spot (see section 4.2). However, surveying the deeper interior of the ice block can be extremely useful before the selection of the drilling spot. Ground Penetrating Radar (GPR) is capable imaging the internal structure of the ice and its basal topography (Hausmann and Behm, 2011; Colucci et al., 2014; Gómez Lende et al., 2016; Munroe, 2021). GPR survey of the ice block not only helps to avoid the sectors of the cave ice with embedded rocks but also provides information about the thickness of ice cave deposits hence finding the thickest accessible cave ice sequence.

The combination of all these factors generally leads to a complex stratigraphy of any cave ice block, making a unitary interpretation rather impossible. To address these challenges, we have developed 1) a dedicated drilling device for cave glaciers (Murariu et al., 2013) and 2) a "Cave Ice Sedimentary architecture and deposition (CISAD)" approach to investigating subterranean cave ice deposits. This approach has been used in several past (Perşoiu et al., 2017; Bădăluță et al., 2020) and ongoing studies in caves in Romania, Norway, Greece, Slovakia, Slovenia, Croatia etc.

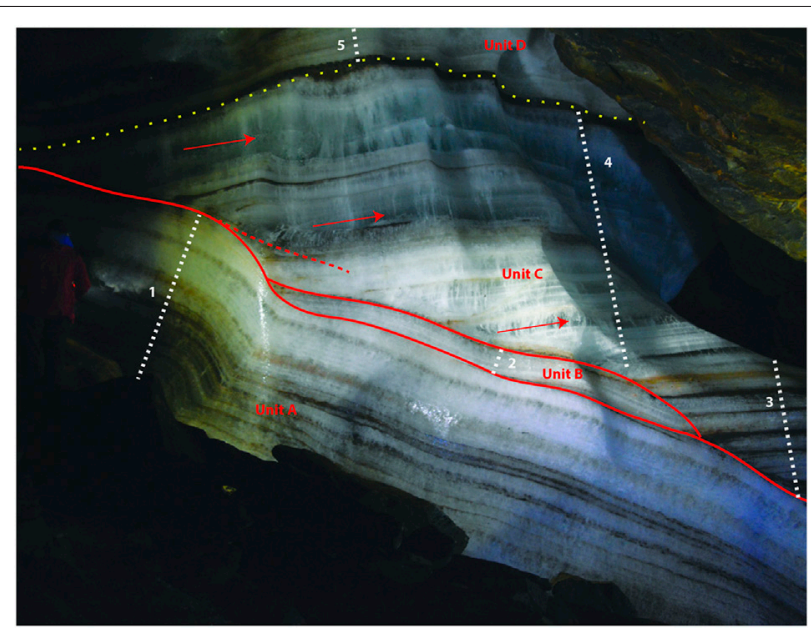

FIGURE 3 | The lower section of the ice block in Svarthammarhola, Cave, Norway. The red arrows indicate layers of clear ice, formed as ponds of water frozen from top to bottom. The red dashed line indicates the (potential) former top of Unit A. The stippled yellow line indicates a massive flooding episode. The white dashed lines (1-5) indicate the longest potential paleoclimate record. The caver on the left is $\sim 1.80 \mathrm{~m}$ tall.

\section{Cave Ice Drilling Auger}

The ISER-HD ${ }^{1}$ auger is a modified PICO electric drill (Koci and Kuivinen, 1984), build by Heavy Duties SRL (ClujNapoca, Romania). It consists of a core barrel with a cutting head, extension rods and a $220 \mathrm{~V}$ driving engine (Murariu et al., 2013). The barrel is $100 \mathrm{~cm}$ long and with an interior diameter of $10 \mathrm{~cm}$. In addition to the original PICO device, the cutting head was fitted with four cutters made of $42 \mathrm{CrMo} 4$ alloy steel, with a rake (leading) angle of $30^{\circ}$ (may vary from $30^{\circ}$ to $45^{\circ}$ ) and a relief angle of $10^{\circ}$ (may vary from $10^{\circ}$ to $15^{\circ}$ ). The slightly lower angles of the main cutters were chosen to allow for slower penetration under low power in the

${ }^{1}$ Emil Racoviță Institute of Speleology - Heavy Duty 
cave ice deposits with a density far higher than that of surface ice in mountain and polar glaciers. Additionally, the low angles allow for easier cutting through layers of CCC up to $3 \mathrm{~cm}$ thick and through occasional wood found in ice (Bădăluță et al., 2020). Adjustment screws were incorporated between the cutters to regulate the penetration speed. Both the screws and the cutters were fitted with screws to allow for quick replacement in the field, as the presence of CCC and allochthonous dues worn out the cutting edge. In the few cases when a thin layer of refrozen water and CCC formed an impenetrable hard surface at the bottom of the drillhole, the adjustment screws were replaced with long screws reaching below the main cutters and these were used to break-up the refrozen layer. The cutting head has two helical paths that direct the ice chips towards similarly placed helical spirals along the barrel and further inside it, through several $30 \mathrm{~cm}$ diameter holes. Two spring-loaded core dogs were fitted to the cutting head to hold the core after each run. The extension rods are made of aluminum alloy 6060 (Murariu et al., 2013) and the engine is a $220 \mathrm{~V}, 1.8 \mathrm{~kW}$ reversible engine, with a variable maximum speed of 1,300 rpm. This device was tested in two ice caves in Romania, Scărișoara Ice Cave and Focul Viu ice Cave, on several occasions between 2012 and 2016. The drilling auger has been deployed to drill both vertically and horizontally, allowing the recovery of ice core down to a depth of $25 \mathrm{~m}$ below surface (Bădăluță et al., 2018), using power drawn from both the national electric grid and a gasoline generator. The main problems and solution we have encountered are listed in Table 2.

\section{Cave Ice Sedimentary Architecture and Deposition (CISAD) Approach}

Forced by the shape of the cave passage system, cave ice deposits often have complex geometries (Gómez-Lende and SánchezFernández, 2018) and dynamic processes active in ice caves regularly obscure and/or modify further the original morphology and stratigraphy of the perennial ice blocks targeted by drilling efforts. Consequently, the assumption that an ice core drilled vertically through the ice block will intersect only chronologically ordered layers is often falsified by the findings (see for example figures in Holmlund et al., 2005; Stoffel et al., 2009; Spötl et al., 2014; Lauritzen et al., 2018). These problems are mainly affecting smaller cave glaciers, whereas large ice blocks $\left(>30,000 \mathrm{~m}^{3}\right)$ are less affected, at least partly, and layers in stratigraphic order can be drilled (Maggi et al., 2008; Kern et al., 2009; Perşoiu et al., 2017; Bădăluță et al., 2020). However, even such large cave glaciers can be affected by post-depositional processes (Figure 2), with newly formed ice layers covering old ones (Figure 2A) and potential contamination of old ice with modern water and organic matter, tilting of the strata (Figure 2B) and successive periods of melting and accumulation resulting in a complex cut-and-fill structure (Figure 3). The aim of virtually all ice core drilling efforts is to obtain an undisturbed record of past environmental variability but this is hampered by the problems detailed above. To partly address this conundrum, we propose an approach that takes into account the mechanisms leading to ice formation and accumulation and those affecting the already formed ice block.

First, the processes responsible for ice formation must be understood, especially when the stable isotope composition of oxygen and hydrogen in water is the main target. Whereas snow accumulation will likely result in the successive accretion of ice layers preserving the original $\delta^{18} \mathrm{O}$ and $\delta^{2} \mathrm{H}$ signals of snow and thus the climatic information it holds (e.g., Belmonte Ribas et al., 2014; Munroe et al., 2018), freezing of water is accompanied by complex fractionation processes (Perşoiu et al., 2011). Ice blocks formed through this process could have layers that froze from very thin water films and these, while also affected by kinetic fractionation, will likely preserve the original $\delta^{18} \mathrm{O}$ and $\delta^{2} \mathrm{H}$ values, in a manner similar to ice wedges (e.g., Meyer et al., 2015). Contrary, downward freezing of stagnant pools of water will result in an ice layer with a strong $\delta^{18} \mathrm{O}$ and $\delta^{2} \mathrm{H}$ gradient (Perşoiu et al., 2011), with the upper (first to freeze) layer enriched in the heavy isotopes $\left({ }^{18} \mathrm{O}\right.$ and $\left.{ }^{2} \mathrm{H}\right)$. Consequently, drilling through such a layer will yield a stable isotope gradient, potentially be interpreted as indicating a climatic change, albeit a false one. Therefore, analyzing the stable isotope composition of ice core retrieved from cave ice deposits requires the identification of genetic layers, either in ice cores or in the field (Figure 3) and sampling should be done considering this layering. For example, the ice layers indicated by red arrows in Figure 3 likely formed as shallow pools of water froze. The stable isotope composition of oxygen and hydrogen in that ice would reflect that of the original water (and thus hold a putative climatic information) only of the entire layer of ice is considered as one sample-and thus drilling should be made accordingly.

Second, the post depositional processes affecting any ice block result in often complex stratigraphy, that preserves the history of the glacier but not always that of the climate changes during its lifetime. Before drilling for a continuous record of past climate change, this stratigraphic history must be understood (Citterio et al., 2003; Stoffel et al., 2009). For example, the ice block shown in Figure 3 (Svarthammarhola, Norway), underwent several episodes of melting, tilting and accumulation. The structure and composition of the lower layers (unit A), suggest slow freezing of shallow pools of water. Several episodes of enhanced melting with inflow of external water carrying soil and macrofossils (dark layers in the lower half of unit A) interrupted this accumulation. The upper part of unit A was likely affected by a severe melting episode, that led to the removal of part of it (Figure 3). On top of this truncated unit A, a new layer of ice formed-unit B. Melting at the sole of the glacier tilted the block, leading to the inclined appearance of both units A and B. Subsequently, shallow ponds formed on top of unit B and a new unit started to develop-unit C. Depending on location, this unit is between 0.5 and $4.4 \mathrm{~m}$ thick (see the left and right ends of unit $\mathrm{C}$ in Figure 3). The ice layers within unit $\mathrm{C}$ are a combination of lake ice and floor ice. A severe flooding episode likely affected the ice block (thick brown layer capping unit C) and ice accumulation resumed afterwards, with both lake and floor ice 
accumulating (unit D). The consequence of these different processes is that a continuous ice core cannot be directly extracted from the sequence shown in Figure 3. First, the likely loss of ice due to the melting events that truncated units $\mathrm{A}, \mathrm{C}$ and possibly B resulted in the loss of continuity of the record. Second, depending on the position of a potential core, the age of successive ice layers could be very different. Third, the genetically different types of ice layers visible in unit $\mathrm{C}$, must be targeted differently in order to obtain meaningful stable isotope data (the strong kinetic fractionation associated with the freezing of lake water shown by the red arrows likely resulted in extremely variable $\delta^{18} \mathrm{O}$ and $\delta^{2} \mathrm{H}$ values). Fourth, freezing, melting, refreezing and inflow of water mixed the organic matter that could provide a chronological anchor for the entire sequence. The layers capping units A, B and C likely contain a mixture of 1 ) organic matter derived from the top of any of the considered units following melting, 2) material transported during the melt event and 3) material deposited when accumulation resumed. In this case, as well as in others (Perşoiu and Pazdur, 2011; Spötl et al., 2014; Kern et al., 2018; Munroe et al., 2018; Sancho et al., 2018), this sequence of events could have been separated in time by years or centuries, thus preventing the formation and preservation of a continuous sequence of climatic events. The white dashed lines numbered one to five shown in Figure 3 suggest the potential location of drilling efforts that would maximize the length of a paleoclimate record. Obviously, vertical drilling would totally miss this, hence horizontal drilling is the only possible course of action.

In the light of the above, we propose the following approach-which we call the Cave Ice Sedimentary Architecture and Deposition (CISAD) approach-in establishing the location of a drilling site best-suited to obtain valuable paleoclimate data. The morphology of ice caves usually allows drilling to be performed either vertically or laterally (i.e., on a layer-by-layer approach, Figure 2B), depending on the results of the CISAD analyses.

1. Detailed stratigraphic investigation of the ice sequence and delimitation of genetically unitary stratigraphic units

2. Identification of the ice layer forming processes (snow accumulation, freezing of water as either floor or lake ice), uniquely important for the interpretation of stable isotope data.

3. Establishment of the chronology of ice deposition, separately for each stratigraphic unit. The most important one and also the most difficult to date are the layers separating individual units, we thus recommend

\section{REFERENCES}

Bădăluță, C.-A., Perşoiu, A., Ionita, M., and Piotrowska, N. (2020). Stable Isotopes in Cave Ice Suggest Summer Temperatures in East-central Europe Are Linked to Atlantic Multidecadal Oscillation Variability. Clim. Past 16, 2445-2458. doi:10.5194/cp-16-2445-2020

Bădăluță, C. A., Perşoiu, A., Ionită, M., and Piotrowska, N. (2018). Proceedings of the $8^{\text {th }}$ International Workshop on Ice Caves. Spain: Potes, 20.Summer Climate Changes during the Last 1000 Years as Seen in Cave Ice avoiding them and target the layer closest to the bottom and top of the unit that contain datable material $\left({ }^{14} \mathrm{C},{ }^{3} \mathrm{H}\right)$. While this methodology will inevitably lead to the loss of continuity (but we stress that this has been already lost if unconformities are present in the sequence) and of "some" years from a potentially long record, it nevertheless is the only one that offers trustful ages.

4. Correlation of the "floating" records based on relative positions (stratigraphy-based), rather than on depth below surface (above bottom) or chronology. The later issue is especially important, as, depending on the process affecting an ice block in the past, different parts of it could preserve partly overlapping sequences, but which could be discontinuous and hence the desire to obtain continuous records might lead to erroneous results.

5. Detailed knowledge of the ice forming mechanism(s) and of those responsible for proxy incorporation in ice (e.g., stable isotopes, pollen) are mandatory.

\section{AUTHOR CONTRIBUTIONS}

ZK and AP designed the project and contributed equally to the writing of the manuscript.

\section{FUNDING}

This work was supported by a grant of the Romanian Ministry of Education and Research, CNCS - UEFISCDI, project numbers PNIII-P1-1.1-TE-2016-2210 and PN-III-P4-ID-PCE-2020-2723, within PNCDI III, awarded to AP. This study was financially supported by the EEA Grants 2014-2021 under Project EEA126 (KARSTHIVES), contract no. 3/2019.

\section{ACKNOWLEDGMENTS}

We thank the numerous friends who helped us during fieldwork (Carmen, Vlad, Christos, Yorgos, Nenad, Neven, Viorica, Stavros, Ioanna, Bospor, Tasos, Mike, Ioana, Christian, Geza, Stein-Erik, Cristina, Traian, Denisa, Corina and many others). The friendly IWIC meetings offered excellent venues to discuss problems, ideas, challenges, failures - we thank all organizers, hosts, sponsors and participants for the stimulating environment they created. This is contribution No. 77. of 2 ka Palæoclimatology Research Group.

Barton, H. A., Breley, G. J., Tochterle, P., and Moseley, G. E. (2020). Cryogenic Features of the Permafrost Ice Caves of Grottedal, Northeast Greenland. Cave Karst Sci. 47, 93-99.

Belmonte-Ribas, A., Sancho, C., Moreno, A., Lopez-Martinez, J., and Bartolome, M. (2014). Present-day Environmental Dynamics in Ice Cave A294, Central Pyrenees, Spain Geografia Fisica \& Dinamica Quaternaria 37/2, 131-140. doi:10.4461/GFDQ.2014.37.12

Brad, T., Itcus, C., Pascu, M.-D., Perșoiu, A., Hillebrand-Voiculescu, A., Iancu, L., et al. (2018). Fungi in Perennial Ice from Scărișoara Ice Cave (Romania). Sci. Rep. 8, 10096. doi:10.1038/s41598-018-28401-1 
Carey, A. E., Smith, D. F., Welch, S. A., Tičar, J., Zorn, M., Lipar, M., et al. (2020). Shallow Ice Core Profiles from Snežna Cave, Slovenia. Aragonit 25/1, 39.

Cecil, L. D., Green, J. R., Vogt, S., Michel, R., and Cottrell, G. (1998). Isotopic Composition of Ice Cores and Meltwater from Upper Fremont Glacier and Galena Creek Rock Glacier, Wyoming. Geografiska Annaler: Ser. A, Phys. Geogr. 80, 287-292. doi:10.1111/j.0435-3676.1998.00044.x

Citterio, M., Turri, S., Bini, A., and Maggi, V. (2004). Observed Trends in the Chemical Composition, $\delta^{18} \mathrm{O}$ and crystal Sizes vs. Depth in the First Core from the LoLc 1650 “Abisso Sul Margine Dell'Alto Bregai” Ice Cave (Lecco, Italy). Theor. Appl. Karstology 17, 45-50.

Citterio, M., Turri, S., Bini, A., and Maggi, V. (2003). "Some Observtions on the Structure and Morphology of an Ice deposit in the " Abisso suI Margine Dell' Alto Bregai " Cave (Grigna Settentrionale, Italian Alps)," in Proc. VI Symposium of the UIS-GLACKIPR IntI. Commission, Ny-Alesund (Svalbard, Norway), 3-8 Sept. 2003.

Colucci, R. R., Fontana, D., and Forte, E. (2014). "Characterization of Two Permanent Ice Cave Deposits in the southeastern Alps (Italy) by Means of Ground Penetrating Radar (GPR)," in Proceedings of the Sixth International Workshop on Ice Caves, August 17-22, Idaho Falls, Idaho, USA: NCKRI Symposium 4. Editors L. Land, Z. Kern, V. Maggi, and S. Turri (Carlsbad (NM): National Cave and Karst Research Institute), 33-39.

Colucci, R. R., Fontana, D., Forte, E., Potleca, M., and Guglielmin, M. (2016a). Response of Ice Caves to Weather Extremes in the Southeastern Alps, Europe. Geomorphology 261, 1-11. doi:10.1016/j.geomorph.2016.02.017

Colucci, R. R., Forte, E., Maggi, V., Stenni, B., Barbante, C., Bertò, M., et al. (2016b). "The Vasto Ice Cave in the South-Eastern Alps, Europe: Preliminary Results from an Ice Core Analysis," in 7th International Workshop on Ice Caves (IWIC VII) (Postojna), 42-43.

Colucci, R. R., Luetscher, M., Forte, E., Guglielmin, M., Lanza, D., Princivalle, F., et al. (2017). First alpine Evidence of in Situ Coarse Cryogenic Cave Carbonates (CCCcoarse) Geografia Fisica \& Dinamica Quaternaria 40, 53-59.

Dansgaard, W. (2004). Frozen Annals Greenland Ice Sheet Research. Odder, Denmark: Narayana Press.

Dickfoss, P. V., Betancourt, J. L., Thompson, L. G., Turner, R. M., and Tharnstrom, S. (1997). History of Ice at Candelaria Ice Cave, New Mexico. New Mexico Bur. Mines Mineral Resour. Bull. 156, 91-112.

Feurdean, A., Perşoiu, A., Pazdur, A., and Onac, B. P. (2011). Evaluating the Palaeoecological Potential of Pollen Recovered from Ice in Caves: A Case Study from Scărişoara Ice Cave, Romania. Rev. Palaeobotany Palynology 165, 1-10. doi:10.1016/j.revpalbo.2011.01.007

Fórizs, I., Kern, Z., Nagy, B., Szántó, Zs., Palcsu, L., and Molnár, M. (2004). Environmental Isotope Study on Perennial Ice in the Focul Viu Ice Cave, Bihor Mts., Romania. Theor. Appl. Karstology 17, 61-69.

Ginot, P., Stampfli, F., Stampfli, D., Schwikowski, M., and Gäggeler, H. W. (2002). FELICS, a New Ice Core Drilling System for High-Altitude Glaciers. Mem. Nat. Inst. Polar Res. 56, 38-48.

Gómez Lende, M., Serrano, E., Bordehore, L. J., and Sandoval, S. (2016). The role of GPR techniques in determining ice cave properties: Peña Castil ice cave, Picos de Europa. Earth Surf. Process. Landforms 41 (15), 2177-2190. doi:10.1002/ esp. 3976

Gómez-Lende, M., and Sánchez-Fernández, M. (2018). Cryomorphological Topographies in the Study of Ice Caves. Geosciences 8, 274. doi:10.3390/ geosciences 8080274

Hausmann, H., and Behm, M. (2011). Imaging the Structure of Cave Ice by Ground-Penetrating Radar. The Cryosphere 5, 329-340. doi:10.5194/tc-5-3292011

Holmlund, P., Onac, B. P., Hansson, M., Holmgren, K., Mörth, M., Nyman, M., et al. (2005). Assessing the Palaeoclimate Potential of Cave Glaciers: the Example of the Scărişoara Ice Cave (romania). Geografiska Annaler: Ser. A, Phys. Geogr. 87, 193-201. doi:10.1111/j.0435-3676.2005.00252.x

Itcus, C., Pascu, M. D., Lavin, P., Perşoiu, A., Iancu, L., and Purcarea, C. (2018). Bacterial and Archaeal Community Structures in Perennial Cave Ice. Sci. Rep. 8, 15671. doi:10.1038/s41598-018-34106-2

Jouzel, J. (2013). A Brief History of Ice Core Science over the Last 50 Yr. Clim. Past 9 (6), 2525-2547. doi:10.5194/cp-9-2525-2013

Kern, Z., Bočić, N., and Sipos, G. (2018). Radiocarbon-Dated Vegetal Remains from the Cave Ice Deposits of Velebit Mountain, Croatia. Radiocarbon 60, 1391-1402. doi:10.1017/RDC.2018.108
Kern, Z. (2018). "Dating Cave Ice Deposits," in "Dating Cave Ice Deposits" in Ice Caves. Editors A. Perșoiu and S. E. Lauritzen (Elsevier), 109-122. doi:10.1016/ b978-0-12-811739-2.00005-x

Kern, Z., Fórizs, I., Kázmér, M., Nagy, B., Szántó, Zs., Gál, A., et al. (2004). Late Holocene environmental changes recorded at Ghețarul de la Focul Viu, Bihor Mts, Romania. Theor. Appl. Karstology 17, 51-60.

Kern, Z., Fórizs, I., Pavuza, R., Molnár, M., and Nagy, B. (2011a). Isotope Hydrological Studies of the Perennial Ice deposit of Saarhalle, Mammuthöhle, Dachstein Mts, Austria. The Cryosphere 5, 291-298. doi:10.5194/tc-5-291-2011

Kern, Z., Molnár, M., Perşiou, A., and Nagy, B. (2007b). "Radiochemical and Stratigraphic Analysis of Two Ice Cores from Borțig Ice Cave, Apuseni Mts, Romania," in Proceedings of the 2nd International Workshop on Ice Caves. Editor J. Zelinka (Liptovský Mikuláš), 65-69.

Kern, Z., Molnár, M., Svingor, É., Perşoiu, A., and Nagy, B. (2009). Highresolution, Well-Preserved Tritium Record in the Ice of Bortig Ice Cave, Bihor Mountains, Romania. The Holocene 19, 729-736. doi:10.1177/ 0959683609105296

Kern, Z., Surányi, G., Molnár, M., Nagy, B., and Balogh, D. (2007a). “Investigation of Natural Perennial Ice Deposits of Durmitor Mts, Montenegro," in Proceedings of the 2nd International Workshop on Ice Caves. Editor J. Zelinka (Liptovský Mikuláš), 70-73.

Kern, Z., Széles, E., Horvatinčić, N., Fórizs, I., Bočić, N., and Nagy, B. (2011b). Glaciochemical Investigations of the Ice deposit of Vukušić Ice Cave, Velebit Mountain, Croatia. The Cryosphere 5, 485-494. doi:10.5194/tc-5-485-2011

Koci, B. R., and Kuivinen, K. C. (1984). The PICO Lightweight Coring Auger. J. Glaciol. 30 (105), 244-245. doi:10.1017/s0022143000006018

Krainer, K., Bressan, D., Dietre, B., Haas, J. N., Hajdas, I., Lang, K., et al. (2015). A 10,300-Year-Old Permafrost Core from the Active Rock Glacier Lazaun, Southern Ötztal Alps (South Tyrol, Northern Italy). Quat. Res. 83, 324-335. doi:10.1016/j.yqres.2014.12.005

Kwiecien, O., Braun, T., Brunello, C. F., Faulkner, P., Hausmann, N., Helle, G., et al. (2022). What We Talk About When We Talk About Seasonality - A Transdisciplinary Review. Earth-Sci. Rev. 103843. doi:10.1016/ j.earscirev.2021.103843

Langway, C. C., Jr. (2008). The History of Early Polar Ice Cores. Cold Regions Sci. Tech. 52 (2), 101-117. doi:10.1016/j.coldregions.2008.01.001

Langway, C. C., Shoji, H., Mitani, A., and Clausen, H. B. (1993). Transformation Process Observations of Polar Firn to Ice. A. Glaciology. 18, 199-202. doi:10.3189/S026030550001150210.1017/s0260305500011502

Lauritzen, S. E., Baastad, L., Bjørlien, J., Fedje, E., and Holmlund, P. (2005). “The Svarthamar Cave Research Project, Fauske, north Norway," in Proceedings of the 14th International Congress of Speleology, August 2005 (AthenKalamos), 1-5.

Lauritzen, S. E., Baastad, L., and Engelien, J. (2018). in "Ice Caves in Norway, Fennoscandia and the Arctic" in Ice Caves. Editors A. Perșoiu and S. E. Lauritzen (Elsevier), 237-262.

Leunda, M., González-Sampériz, P., Gil-Romera, G., Bartolomé, M., BelmonteRibas, Á., Gómez-García, D., et al. (2019). Ice Cave Reveals Environmental Forcing of Long-Term Pyrenean Tree Line Dynamics. J. Ecol. 107, 814-828. doi:10.1111/1365-2745.13077

Luetscher, M., Bolius, D., Schwikowski, M., Schotterer, U., and Smart, P. L. (2007). Comparison of Techniques for Dating of Subsurface Ice from Monlesi Ice Cave, Switzerland. J. Glaciol. 53, 374-384. doi:10.3189/ 002214307783258503

Luetscher, M., Lismonde, B., and Jeannin, P.-Y. (2008). Heat Exchanges in the Heterothermic Zone of a Karst System: Monlesi Cave, Swiss Jura Mountains. J. Geophys. Res. 113, F02025. doi:10.1029/2007JF000892

Maggi, V., Meyer, C., Leoni, B., Nava, V., Maspero, F., and Pflitsch, A. (2020). Chemical and Physical Stratigraphy of the Schellenberger Eishole Ice Core. Aragonit 25, 48.

Maggi, V., Turri, S., Bini, A., and Udisti, R (2008). "2500 Year of History in Focul Viu Ice Cave," in Proceedings of the 3rd International Workshop on Ice Caves. Editors O. Kadebskaya, B. R. Mavlyudov, and M. Pyatunin (Perm): Mining Institute of Ural Branch of the Russian Academy of Sciences), 11-15.

Mavlyudov, B. R. (2018). "Geography of Cave Glaciation," in "Geography of Cave Glaciation" in Ice Caves. Editors A. Perșoiu and S. E. Lauritzen (Elsevier), 209-220. doi:10.1016/B978-0-12-811739-2.00012-7 
Mavlyudov, B. R. (2008). Oledenenie Pesher (Caves Glaciation). Moscow: Institute of Geography of the Russian Academy of Science, 290. (in Russian).

May, B., Spötl, C., Wagenbach, D., Dublyansky, Y., and Liebl, J. (2011). First Investigations of an Ice Core from Eisriesenwelt Cave (Austria). The Cryosphere 5, 81-93. doi:10.5194/tc-5-81-2011

Meyer, H., Opel, T., Laepple, T., Dereviagin, A. Y., Hoffmann, K., and Werner, M. (2015). Long-term winter Warming Trend in the Siberian Arctic during the Mid- to Late Holocene. Nat. Geosci 8, 122-125. doi:10.1038/ngeo2349

Mondini, A., Donhauser, J., Itcus, C., Marin, C., Perșoiu, A., Lavin, P., et al. (2019). High-throughput Sequencing of Fungal Communities across the Perennial Ice Block of Scărișoara Ice Cave. Ann. Glaciol. 59, 134-146. doi:10.1017/aog.2019.6

Munroe, J. S. (2021). First Investigation of Perennial Ice in Winter Wonderland Cave, Uinta Mountains, Utah, USA. The Cryosphere 15, 863-881. doi:10.5194/ tc-15-863-2021

Munroe, J. S., O'Keefe, S. S., and Gorin, A. L. (2018). Chronology, Stable Isotopes, and Glaciochemistry of Perennial Ice in Strickler Cavern, Idaho, USA. GSA Bull. 130, 175-192. doi:10.1130/b31776.1

Murariu, V., Pacurar, A., and Gyenge, Cs. (2013). New Ice Core Drilling Machine for Small Glaciers. ACTA TECHNICA NAPOCENSIS 56/2, 411-414.

Oeschger, H., Schotterer, U., Stauffer, B., Haeberli, W., and Röthlisberger, H. (1977). First Results from Alpine Core Drilling Projects. Z. für Gletscherkunde Glazialgeologie 13, 193-208.

Onac, B. P., Baumann, S. M., Parmenter, D. S., Weaver, E., and Sava, T. B. (2020). Late Holocene Droughts and Cave Ice Harvesting by Ancestral Puebloans. Sci. Rep. 10, 20131. doi:10.1038/s41598-020-76988-1

Onac, B. P., Parmenter, D. S., Weaver, E., Baumann, S. M., and Sava, T. B. (2018). Ice deposits in lava tubes of El Malpais National Monument, New Mexico (USA). in Proceedings of the 8th International Workshop on Ice Caves, Potes, Spain, 19

Opel, T., Meyer, H., Wetterich, S., Laepple, T., Dereviagin, A., and Murton, J. (2018). Ice Wedges as Archives of winter Paleoclimate: A Review. Permafrost and Periglac Process 29, 199-209. doi:10.1002/ppp.1980

Paun, V. I., Icaza, G., Lavin, P., Marin, C., Tudorache, A., Perşoiu, A., et al. (2019). Total and Potentially Active Bacterial Communities Entrapped in a Late Glacial through Holocene Ice Core from Scarisoara Ice Cave, Romania. Front. Microbiol. 10, 1193. doi:10.3389/fmicb.2019.01193

Perșoiu, A., Onac, B. P., Wynn, J. G., Blaauw, M., Ionita, M., and Hansson, M. (2017). Holocene winter Climate Variability in Central and Eastern Europe. Sci. Rep. 7 (1), 1196. doi:10.1038/s41598-017-01397-w

A. Perşoiu and S. E. Lauritzen (Editors) (2018). Ice Caves (Elsevier).

Perşoiu, A., Buzjak, N., Onaca, A., Pennos, C., Sotiriadis, Y., Ionita, M., et al. (2021). Record Summer rains in 2019 Led to Massive Loss of Surface and Cave Ice in SE Europe. The Cryosphere 15, 2383-2399. doi:10.5194/tc-15-2383-2021

Perşoiu, A. (2018). "Ice Dynamics in Caves," in Ice Caves. Editors A. Perşoiu and S. E Lauritzen (Elsevier), 97-108.

Perşoiu, A., Onac, B. P., Wynn, J. G., Bojar, A.-V., and Holmgren, K. (2011). Stable Isotope Behavior during Cave Ice Formation by Water Freezing in Scărişoara Ice Cave, Romania. J. Geophys. Res. 116, D02111. doi:10.1029/2010JD014477

Perşoiu, A., and Onac, B. P. (2019). "Ice in Caves" in Encyclopedia of Caves. Academic Press, 553-558.

Perşoiu, A., and Pazdur, A. (2011). Ice Genesis and its Long-Term Mass Balance and Dynamics in Scărişoara Ice Cave, Romania. The Cryosphere 5, 45-53. doi:10.5194/tc-5-45-2011

Pflitsch, A., Schörghofer, N., Smith, S. M., and Holmgren, D. (2016). Massive Ice Loss from the Mauna Loa Icecave, Hawaii. Arctic, Antarctic, Alpine Res. 48, 33-43. doi:10.1657/AAAR0014-095

Rand, J., and Mellor, M. (1985). Ice-coring Augers for Shallow Depth Sampling. CRREL Rep., 85-21.

Sancho, C., Belmonte, Á., Bartolomé, M., Moreno, A., Leunda, M., and LópezMartínez, J. (2018). Middle-to-late Holocene Palaeoenvironmental Reconstruction from the A294 Ice-Cave Record (Central Pyrenees, Northern Spain). Earth Planet. Sci. Lett. 484, 135-144. doi:10.1016/j.epsl.2017.12.027
Sattler, B., Larch, P., Rambacher, J., and Spötl, C. (2013). Das Eis der Hundsalm Eisund Tropfsteinhöhle als Lebensraum für mikrobielle Gemeinschaften. Die Höhle 64, 15-24.

Serban, M., Blaga, L., Blaga, L., Chifu, A., and Ciobotaru, T. (1967). Contribuții la stratigrafia depozitelor de gheața din Ghețarul de la Scărișoara. Lucrarile Institutului de Speologie "Emil Racovita 6, 107-140.

Serban, M., Coman, D., and Givulesco, R. (1948). Decouvertes récentes et observations sur la glacière naturelle dite Ghearul de la Scărișoara. Bull. Soc. Hist. Natur. Sci. Cluj X, 174-210.

Spötl, C., Reimer, P. J., and Luetscher, M. (2014). Long-term Mass Balance of Perennial Firn and Ice in an Alpine Cave (Austria): Constraints from Radiocarbon-Dated wood Fragments. The Holocene 24, 165-175. doi:10.1177/0959683613515729

Stoffel, M., Luetscher, M., Bollschweiler, M., and Schlatter, F. (2009). Evidence of NAO Control on Subsurface Ice Accumulation in a 1200 Yr Old Cave-Ice Sequence, St. Livres Ice Cave, Switzerland. Quat. Res. 72, 16-26. doi:10.1016/j.yqres.2009.03.002

Strug, K., Perşoiu, A., and Zelinka, J. (2008). "Preliminary Results of Ice Temperature Measurements in the Dobšinská Ice Cave (Slovakia) and Scărişoara Ice Cave (Romania,"In Proceedings of the 3rd International Workshop on Ice Caves. Editors O. Kadebskaya, B. R Mavlyudov, and M. Pyatunin (Perm: Mining Institute of Ural Branch of the Russian Academy of Sciences), 16-22.

Talalay, P. G. (2014). Perspectives for Development of Ice-Core Drilling Technology: A Discussion. Ann. Glaciol. 55 (68), 339-350. doi:10.3189/ 2014AoG68A007

Talalay, P., Yang, C., Cao, P., Wang, R., Zhang, N., Fan, X., et al. (2015). Ice-core Drilling Problems and Solutions. Cold Regions Sci. Tech. 120, 1-20. doi:10.1016/ j.coldregions.2015.08.014

Trofimova, E. V., Sokolov, Y. V., and Trofimov, A. A. (2020). Ice in Caves Askinskaya and Kinderlinskaya: Comparative Characteristic. Bull. Russ. Geographical Soc. 152 (2), 70-74. doi:10.31857/S086960712002007X10.17747/ 2311-7184-2020-3-70-74

U.S. Ice Drilling Program (2019). SIPRE Hand Auger Operations and Maintenance Manual. 1-16. Available at: https://icedrill.org/sites/default/ files/8507-0011.pdf.

Vrana, K., Baker, J., Clausen, H. B., Hansen, S. B., Zelinka, J., Rufli, H. O., et al. (2007). "Continental Ice Body in Dobšiná Ice Cave (Slovakia) - Part I. - Project and Sampling Phase of Chemical and Isotopic Study," in Proceedings of the 2nd International Workshop on Ice Caves. Editor J. Zelinka (Liptovský Mikuláš), $24-28$.

Yonge, C. J., Ford, D., Horne, G., Lauriol, B., and Schroeder, J. (2018). “Ice Caves in Canada," in "Ice Caves in Canada" in Ice Caves. Editors A. Perșoiu and S. E Lauritzen (Elsevier), 285-334. doi:10.1016/b978-0-12-811739-2.00015-2

Žák, K., Onac, B. P., and Perşoiu, A. (2008). Cryogenic Carbonates in Cave Environments: A Review. Quat. Int. 187, 84-96. doi:10.1016/ j.quaint.2007.02.022

Conflict of Interest: The authors declare that the research was conducted in the absence of any commercial or financial relationships that could be construed as a potential conflict of interest.

Publisher's Note: All claims expressed in this article are solely those of the authors and do not necessarily represent those of their affiliated organizations, or those of the publisher, the editors and the reviewers. Any product that may be evaluated in this article, or claim that may be made by its manufacturer, is not guaranteed or endorsed by the publisher.

Copyright (๑) 2022 Kern and Perşoiu. This is an open-access article distributed under the terms of the Creative Commons Attribution License (CC BY). The use, distribution or reproduction in other forums is permitted, provided the original author(s) and the copyright owner(s) are credited and that the original publication in this journal is cited, in accordance with accepted academic practice. No use, distribution or reproduction is permitted which does not comply with these terms. 